\title{
The Meaning of the Motif of Michael the Archangel's Dispute with the Devil (Jude 9). A Socio-Rhetorical Perspective ${ }^{1}$
}

\author{
DOROTA MUSZYTOWSKA \\ Faculty of Humanities, Cardinal Stefan Wyszyński University in Warsaw \\ e-mail: d.muszytowska@uksw.edu.pl \\ ORCID: 0000-0001-5873-382X
}

\begin{abstract}
The purpose of this article is to analyse the persuasive functions of the Archangel Michael motif in the Epistle of Jude 9, and examine how the laconic reference serves argumentation in the letter and how it affects the recipients. We used methods of interpretation from the field of socio-rhetoric according to the interpretation model developed by Vernon K. Robbins, adapted to the needs of this study: rhetorical analysis, intertextual relations, and analysis of the pivotal values of the first-century Mediterranean world. The analyses lead to the conclusion that the condensed form of the reference to the Archangel Michael motif makes it possible to refer to the crisis among the addressees on many levels at the same time. It serves positive argumentation based on the ethos, uses the strength of the rich interpretative tradition of the motif and proves to be the key to the proper implementation of the answer within the challenge-riposte mechanism and to defining the threat to the communal identity.
\end{abstract}

Keywords: Epistle of Jude 9; Archangel Michael; exemplum; socio-rhetoric; intertextuality; honour and shame; patron-client institution

\section{Introduction}

The characteristic feature of the Epistle of Jude are its numerous references to other texts and traditions. In this paper, we would like to take a closer look at the motif of the dispute between Michael the Archangel and the devil over the body of Moses. In their treatment of this passage, most commentators of the Epistle of Jude tend to focus on the issue of the primary source of the citation, as it is far from obvious. ${ }^{2}$ Scholars were strongly influenced by the hypothesis put forth by Richard Bauckham of a probable text that might have been used by

2 Ancient sources support the hypothesis that the author of the Epistle of Jude used here a quote drawn from the final of a work known as The Assumption of Moses. We will return to this problem in the section on intertextuality. 
the author of the Epistle of Jude. ${ }^{3}$ The reconstruction submitted by Bauckham has been subjected to criticism, but that has not led to any satisfactory answers regarding the origin and range of the reference presented in the Epistle of Jude 9. ${ }^{4}$

Within the scope of this study, it will be impossible to determine the origin of the passage, an issue specific to historical and critical research. Instead, we are particularly interested in the persuasive qualities of the motif, regarded from the perspective of synchronic research. We intend to analyse the purpose the author might have had in using the allusion to the motif, the role attributed to this reference in his argument, and the connotations associated therewith. At this point, of particularly importance for us is the potential that motif has in affecting the readers of the text. Besides the persuasive function, as envisaged by the author, we are also concerned with the factors influencing the readers regardless of the author's invention and will, as a result of their own context. Given the limitations of the article form, we are going to focus exclusively on the reader intended by the author, and not our contemporaries. Neither do we want to limit our analysis to the persuasive and communication aspects of the language used. It is a crucial matter insofar as the Epistle of Jude may be considered a reaction to the conflict within the community or threats to its identity and the purity of its members' faith; a threat emerging from within it. That is why we are committed to discovering the mechanisms influencing the then ongoing discourse. We are going to use socio-rhetorical models of interpretation as tools from the rich field of discourse analysis, enabling us to broaden the research perspective, as in principle we aim at describing and interpreting communication phenomena within their social context.

We have selected the socio-rhetorical model of text interpretation developed by Vernon K. Robbins ${ }^{5}$ as the method for our research due to its underlying as-

3 The hypothesis was first presented in an excursion and later in the commentary to the Epistle of Jude, see R. Bauckham, Jude, 2 Peter (WBC 50; Grand Rapids, MI: Zondervan 1983) 65-76, then revised and further developed in a subsequent monograph: R. Bauckham, Jude and the Relatives of Jesus in the Early Church (Edinburgh: Clark 1990) 235-280. In his reconstruction, Richard Bauckham presented two recreated closing fragments: one for The Testament of Moses, the other for The Assumption of Moses. He also assumed a possibility of the traditions of both texts being combined.

4 Among the most important works, one ought to rank: the edition and critical commentary to The Assumption of Moses by Johannes Tromp (The Assumption of Moses. A Critical Edition with Commentary [Leiden: Brill 1993]), in the commentary section of which the author referred to Bauckham's reconstruction submitted in the latter's earlier work; and the work by John Muddiman ("The Assumption of Moses and the Epistle of Jude," Moses in Biblical and Extra-Biblical Traditions [eds. A. Graupner et al.] [BZAW 372; Berlin: De Gruyter 2007] 169-180), in which the author evaluates both the initial and the revised argument presented by R. Bauckham. According to Muddiman (ibidem, 180), the weakest point in Bauckham's reconstruction is his use of relatively late Christian sources, perhaps already informed by the Epistle of Jude, particularly as regards the motif of Moses accused of a murder committed in Egypt by Satan, who contests Moses' right to honourable burial.

5 See V.K. Robbins, Exploring the Texture of Texts. A Guide to Socio-Rhetorical Interpretation (Valley Forge, PA: Trinity Press International 1996). 
sumption of performing analysis from diverse points of view. It proved necessary to limit the model in all its sophistication. Firstly, to the three stages of the model, i.e. the inner texture, inter-texture, and the social and cultural texture. Secondly, within these phases of methodological proceeding, we have limited ourselves to using the analysis of argumentative qualities of the text, and then to the intertextual relations to literary traditions, and to the analysis of main categories, typical for the Mediterranean culture of the first century, that is the institution of patron-client and the elements of the social game of challenge and response as the categories unifying the culture and organising the social life within it.

\section{The Motif of Michael the Archangel as an Exemplum}

The initial rationale for the main objective in the given matter, that is the call to contend in the struggle for the entrusted faith (Jude 3), is constituted by the propositio (Jude 4) that delineates the method of argumentation centred on presenting the essence of godlessness along with its consequences in the future. The reference to Michael the Archangel in Jude 9 marks a fragment of that demonstration. It falls within the category of argumentation from example (paradeigma, exemplum), based on logical induction, benefitting from the similarity between the illustration and the discussed case. A reference to an event or a figure serves to persuade the audience of the validity of the presented argument. Should the matter raise doubts of any sort among the addressees - through being either similar or antithetic to something certain, it consequently gains plausibility.

As it is the primary function of an example, the reference to the specific motif of the dispute between Michael the Archangel and the devil is predominantly intended to help the readers accept the propositio and thus to add credibility to the charges presented therein. The example may pertain to all of those indictments, or to a selected one. By definition, the source of the example has to be external to the case, as that is where its persuasive power originates from. The author's task is to demonstrate the connection between the evoked example and the situation under deliberation. The choice of an example tends to be the most difficult aspect of that kind of argumentation, as every instance of incongruence carries with it the risk of causing misunderstanding, and may even end up working against the argued case. The basis for establishing a real connection lies in the use of similarity, dissimilarity, or antithesis, that should be easy for the audience to grasp. The perfect exemplum is of such a character that it requires no additional elaborate commentary, or it is limited to the appropriate words and phrases, such as "similarly," "on the contrary," etc. Therefore, exam- 
ples in argumentation are usually given the form of an uncomplicated allusion (allusio). Meanwhile, if the source that the example has originated in proves far from obvious or the argumentative situation requires it, the example may require to be developed into a narrative, a description, or an additional explanatory commentary. ${ }^{6}$

Looking at the reference to Michael the Archangel and the motif of contention we are analysing with regard to the above characteristics, we may infer that the author is evoking something his readers are readily familiar with, mainly because we find no narrative extension of the motif, nor any additional clarifications by the author. The concise form of expression serves for identification, that is its objective is to direct the readers at the specific oral or textual tradition the author wants to summon up. Due to the fact that we are ignorant of the written source ${ }^{7}$ that the motif had been drawn from, it is difficult to unequivocally determine whether the entire narrative structure of the argument at hand belongs to its original layer; and whether - and if so - in what way it was modified in order to perform that function.

From the point of view of the rhetoric of narration, it seems appropriate to distinguish two levels of expression in the current exemplum. The first would pertain directly to the story the author is referring to. The other would be the statement made by the author of the epistle, who, having assumed the function of the narrator, used his role to show his readers familiar truths in an apposite interpretative framework, in order to bridge the gap between the case at hand and the illustration chosen for the argument.

Within the exemplum, we can identify three utterances. The first comprises the information pointing to the specific motif of contention between Michael and the devil over the body of Moses (Jude 9a: "when the archangel Michael contended with the devil and disputed about the body of Moses"); the other (Jude 9b) is the account that Michael did not dare to judge Satan by himself, nor accuse him of anything; and the third is the potential citation from what Michael said to Satan (Jude 9c: "The Lord rebuke you").

We may tentatively assume the latter element to belong to the original layer of the source narrative. It sounds like the phrase of an exorcism ${ }^{8}$ or a legal expression drawn from the point in a trial, when the judged is presented with a case to evaluate and pronounce the verdict. ${ }^{9}$ In the narrative of the argument, its purpose

6 Cf. H. Lausberg, Handbook of Literary Rhetoric. A Foundation for Literary Study (Leiden - Boston, MA - Köln: Brill 1998) 196-200.

7 The matter of the hypothetical source of the motif will be discussed in the section on its intertextuality.

8 The verb epitimao was frequently used to refer to the subjugation of the forces of Satan by God. Cf.

H.C. Kee, "The Terminology of Mark's Exorcism Stories," NTS 14 (1968) 232-246.

9 Cf. G.L. Green, Jude and 2 Peter (BECNT; Grand Rapids, MI: Baker Academic 2008) 83. 
is to generate sublimity, intended to stir the readers' emotions. The amplification also concerns the logical content, for through such emotional pathos the author may be underscoring the crucial message of his argumentation as to who possesses the power to judge and arrive at the ruling; in this formula, that power is unequivocally surrendered to the Lord as the only one to wield it. Michael, in his essence equal to Satan, does not usurp the authority of God. That way, the author tackles both the charge of denying the power of Jesus Christ, and the charge of hubris. It is an indication that the problems with the attitude of the wicked include that of their appropriation of the right to arbitrate and pass judgements in cases reserved for God.

We may attribute the first and the second utterance in the narrative of the exemplum in Jude 9 both to the message of the source story and to the metanarrative introduced by the author of the Epistle of Jude. The laconic form of both makes us lean towards the hypothesis that the author has already interpreted the motif. The original material might have introduced many other elements of much lower relevance for the unfolding argumentation. The author made a selection, first pointing the story he intended to cover and then to the specific moment in its narrative, finally he added his own commentary describing the attitude assumed by Michael the Archangel in order to focus his audience on its most important aspect. The persuasive force of the pair of phrases is significant in relation to the proposition, regardless of whether the author is directly quoting or paraphrasing the text of a story his readers are familiar with, or whether he is using an original passage, though distinctly alluding to that story's content, by creating a bridge of sorts for the induction to be performed by his addressees.

The exemplum constructed on the basis of this motif refers the reader to the realm of the immaterial, inhabited by spiritual entities, who are, nevertheless, involved with the material aspects of human life (the dispute about the body of Moses). It presents Michael the Archangel opposing the devil as the defender of human matters. It also emphasises Michael's total and unconditional submission to the power of God, for whom he displays great reverence by not usurping the right to pronounce the verdict about Satan.

The evocation of the world of spiritual creatures may apparently bear no clearcut connection to the message expressed in the propositio (Jude 4), as opposed to the obviously shared subject of Lord's authority. However, it pertains directly to the words immediately preceding the argumentation and those directly following it. These share the term for slanderous speech (in verses 8 and 10: blasfemousin; in verse 9: blasfemias). One could consider it to constitute a literary strategy of connection-building, which, however, does not mean a semantic parallel, but 
merely a parallel of expressions in which the indicated words appear. ${ }^{10}$ Instead, it rather indicates the continuity of persuasive effort performed in these verses.

In verse 8 , the author applies a comparison of similarity. He lists three indictments against a typical attitude of the ungodly operating in the community of his addressees: defiling the body, rejecting the authority, and slandering of spiritual beings (doksai), ${ }^{11}$ and opens his sentence with the word "similarly" (homoios), that appertains to all three of them. The faults of the wicked are parallel to the behaviours listed in the preceding three examples (vv. 5-7): the rebellion against God in the desert, the rebellion of angels against God's plan, and wilful sins of the inhabitants of Sodom. The parallel rather emphatically implies punishment to the wicked analogical to the punishments inflicted in those examples. ${ }^{12}$

The motif of Michael the Archangel is particularly to be associated with the example of the aforementioned rebellion of angels against God's plan and their violation of the order instituted by Him (v. 6); however, the principle here is not that of similarity, but of opposition. The illustration in verse 9 has the form of a negation instantiated by a conjunctive particle "but/on the other hand" (de), which introduces a contrast to the preceding content. Hence, Michael the Archangel is most of all the one representing a position antithetical to that assumed by renegade angels and people opposing God, including the ungodly members of the addressees' community, who "reject authority" and "slander the Glorious ones." This opposition is strengthened by the repeated particle "but," in verse 10 , where the author turns back to presenting the stance of the wicked, this time markedly juxtaposing their behaviour to that of Archangel Michael. Hence, the exemplum introduces into the persuasiveness of the Epistle to Jude the force of double contraposition, both with regard the other illustrations drawn from tradition, and as regards the stance of the described ungodly men in the addressed community.

The persuasive power of the example with the motif of the contention between Michael the Archangel and Satan also uses the notion of similarity in an exemplum. For if we refer them to the main argument, the rationale behind the entire reasoning - directed at the addressees of the letter as a call for them to fight for their faith (Jude 3) - then the attitude of Michael the Archangel appears as a positive role model. The author uses the ethos of that figure, presented in a short narrative, and provides his audience with a model to guide their actions by. He does

10 Cf. Bauckham, Jude and the Relatives, 270-271.

11 Commentators of the Epistle of Jude put forth differing readings of the term doksai "the Glorious ones." It may be a reference to the people enjoying a position of affluence and authority, to the angels who remained faithful to God - such meaning is to be found most often in apocalyptical literatureto angels in general, or to God. Cf. for instance P.H. Davids, The Letters of 2 Peter and Jude (Grand Rapids, MI: Eerdmans 2006) 56; F. Mickiewicz, List Świętego Judy. Drugi List Świętego Piotra (NKB.NT 18; Częstochowa: Edycja Świętego Pawła 2018) 95-96.

12 Cf. W.F. Brosend, James and Jude (Cambridge, UK: Cambridge University Press 2004) 174. 
not require any formula indicating such a similarity, because he does not speak of the behaviour of his addressees. Such a formula is in some way inscribed in the actual positioning of the argument from exemplification. It naturally occurs to the reader as a precept: "you do the same." For, by applying this exemplum, the author of the Epistle of Jude introduces a crucial issue of the specific kind of struggle that he demands of his addressees. The combat that he asks his audience to participate in is not to be that of competition or violence, nor of accusation. All the above are contrary to what the behaviour of Michael the Archangel stands for. The scene selected and presented by the author of the Epistle of Jude pertains to the realm of immaterial beings, and hence the battlefield for his readers is to be firstly the spiritual realm. By his entire demeanour and words, the Archangel conveys his submission to God's will, and being like Him in his goodness and profound humility. The author points out to his addressees that it is the best way to triumph over the hubris typical for the godless, in their audacity and promiscuity (aselgeia).${ }^{13}$ In the current exemplum, Michael the Archangel has not entered into a dispute with Satan in order to defeat him, nor to prove to him that he is wrong to establish his own agenda, nor to demonstrate his superiority over him. Neither does the author of the epistle expect the latter behaviours from his addressees towards their miscreants, a view he expresses in the conclusion of the letter (Jude 20-23). The volitional reference to God as the Judge, the only One to settle the contention, indicates that Michael is motivated by God's glory. Thus, the author directs his readers towards the real impulse to undertake the struggle he is calling for. The way Archangel Michael acts in his dispute with Satan stems from his attitude towards God. In everything that he does in that episode, the Archangel is attuned to God, he accepts God's superiority, serving Him and striving for His will to be fulfilled. The very same motivation should drive the ethos of the addressees of the epistle. That includes their attitude towards the disbelievers. Michael the Archangel is well aware of Satan's misbehaviour in opposing God's will. As a result of that, however, he does not decide what should be done with the devil, leaving it to the Lord instead. Nevertheless, he is not passive nor indecisive regarding Satan's actions. It is a clear indication for the readers that they cannot remain passive before ungodly acts, but in their efforts to keep the faith entrusted to them they must be inspirited by the search for God's glory and being obedient to His will in humility, also extended to the heathens. Otherwise, their struggles will prove to be the opposite to what they have been called to, becoming similar to the attitude of the devil from the exemplum.

13 In Greek, the word aselgeia can be used in all these meanings. The context of the Epistle of Jude does not determine unequivocal semantics of the word in the letter; on the contrary, it allows one to consider all of them. 
Analogically, the figure of Satan opposing Michael, introduced in the example, is founded on two principles: that of similarity and antithesis, depending on who it is to be related to. The ungodly act much like him: they oppose God's authority. For the addressees of the letter it serves as a kind of a warning: whenever you act with impudence towards others, and most of all towards God, you, in fact, assume an attitude analogical to that displayed by the devil in his dispute with Archangel Michael. In the form chosen by the author of the letter, there is no definite commentary regarding the former's stance. We may consider it to have been this very sentence that defines the attitude of Archangel Michael. If he does not dare to accuse Satan of his blasphemy, it means that it was an action already performed by Satan, and hence Michel subjects him to God's judgement. ${ }^{14}$ The clarity of the negative evaluation is based on the apparent contrast between the two figures. Obviously, an important role has also been played by the content of the story - the original source of the exemplum - that "worked" in the audience recognising the reference to that narrative. However, even for those ignorant of that story, this counter-positioning is clearly discernible (debate and contention, the opposing attitudes and the words of Michael stemming therefrom, contrary attitudes towards God). Thus, one may assume that it is another form of a commentary by the author of the Epistle of Jude, that his readers are able to understand themselves: you ought not to act like Satan.

Not without its significance in the context of the situation experienced by the community of addressees and the problems they had been faced with is another element in the narrative allusion to the exemplum under consideration; namely, the body (soma) of Moses - the object of contention between Michael and Satan. The simple allusion, modest in elements referring to the source of the exemplum, does not provide a clear-cut answer as to the meaning of the word intended in the original context, nor as to that assumed in the example constructed by the author of the Epistle of Jude. The absence of any such explanation allows us to suppose that the author did not to wish to give the term a meaning different to that it had had in the source story. ${ }^{15}$ The word soma tends to be understood in a physical, material sense, also that of a corpse, but of a man or an animal, too. The most plausible source suggest that the body meant here the corpse of Moses. ${ }^{16}$ Unfortunately, such a meaning introduces a sort of tension into the interpretation of the phrase regarding the defilement of the flesh (sarks) by the ungodly, presented in verse 8, which the exemplum in Jude 9 refers to, thus complicating the issue of similarity and opposition. The crux of the matter lies not in merely a different noun being used. There is a section where the semantic range of the words sarks

\footnotetext{
14 Cf. Mickiewicz, List Świętego Judy, 98.

15 Cf. Green, Jude and 2 Peter, 82.

16 Cf. Tromp, Assumption of Moses, 280.
} 
and soma does overlap (e.g. regarding humanity), and in that narrower meaning, they can be used interchangeably. The pronouncement in verse 8 is perceived in connection to an unspecified abuse of sexuality (hence, sarks has the meaning of the body as the object of desire) through the context of examples in Jude 6-7, i.e. sexual contacts between angels and women, and the sins of the Sodomites. ${ }^{17}$ It might also have been used metaphorically, i.e. to denote the Church, the Body of Christ, or the Eucharist, but such sense would manifest itself as late as in verse 12 , dealing with the participation of the ungodly in feasts, where they are a blemish, a flaw, a stain (spilados). However, it proves rather difficult to associate soma understood as a corpse - the meaning potentially to occur most naturally to the readers of the Epistle of Jude - at least on the basis of what we are able to reconstruct from the letter. Therefore, it seems that the author includes the information about the body of Moses mainly to identify the source of the story, as already suggested.

However, we should not rule out a certain meta-sense associated with the word. In the exemplum, the Archangel represents God's side and expresses His will regarding the corporeity of Moses (regardless of how we conceive of it here). That is why he opposes the devil, who strives to realise his own plans with the body of Moses. Since Michael is contrasted with the attitude of the godless, who defile the flesh, we may assume it to be a certain indication of how the essence of their fault should be understood, but not how to identify their specific behaviour. That would mean that the author intended not so much to consider particular manifestations of what he calls shamelessness (aselgeia), as to underscore the fact that behaviours that in any way involve debasement of the flesh oppose God's plans for man. Thus, they are an equivalent of failing to recognise the Creator's authority and His power over creation.

\section{Persuasive Opportunities Stemming from the Intertextual References of the Archangel Michael Motif}

The Epistle of Jude is regarded by some scholars as an intertextual network, because of the pervasive therein allusions, citations, and comments to other texts. The author transposes the material available to him and his readers, performing a reinterpretation of sorts in order to increase the persuasive force of the argumentation by instilling lasting associations. ${ }^{18}$ The manner that the author deals

17 Cf., for instance, Davids, The Letters, 55-56.

18 Cf. S.J. Joubert, "Facing the Past. Transtextual Relationships and Historical Understanding in the Letter of Jude," BZ 42 (1998) 57. 
with the reference in the Epistle of Jude 9 means that the figure of Michael the Archangel may have been connected to many motifs his addressees were familiar with; hence, the need of pointing to the most appropriate one for the argumentation, helping him add credibility to his thesis (Jude 3-4).

Let us note that we are not dealing with a typical exemplum of a person or a literary character as such, to whom some defined qualities (such as bravery, wisdom, etc.) are attributed, and a reference to their name is sufficient to encompass all these connotations. Nevertheless, we should not exclude the meanings associated with the very figure of Archangel Michael. We can safely suppose that the readers - more or less advertently-interpreted the motif also through the lens of "the definition" of Michael, starting from the meaning of his name: "Who is like God?" (מיכאל), through all the potential qualities and roles ascribed to him and characteristic of him. ${ }^{19}$ The article used before his name in Jude 9 (ho Michael) indicates that either we are dealing with a known person, as he was not mentioned earlier in the text, or the reference to the cited sources means that we are talking about the specific Michael who contended with the devil. For the name Michael was common throughout Jewish communities.

In the biblical text, Michael is not often mentioned by his name. He appears in the apocalyptical texts of Dan 10:13.21, where he is referred to as "one of the chief princes," in Dan 12:1, where he is titled the great prince, whose task it is to protect Israel, ${ }^{20}$ and in Rev 12:7, where he is the commander of the hosts of angels in their fight against Satan. ${ }^{21}$ However, nowhere is he attributed the title of an archangel, besides this single instance in Jude 9. In 1 Thess 4:16, an archangel is mentioned in the context of Christ's parousia, but his actual name is not provided. The article also placed before the noun archangel (ho archaggelos) has the meaning of individualisation, distinguishing Michael from among other archangels, which would mean that the author is referring mainly to the Jewish tradition from outside of the canon, in which Michael is often numbered among the archangels. ${ }^{22}$

19 On the meaning of the name and its etymology, see J.D. Fowler, Theophoric Personal Names in Ancient Hebrew. A Comparative Study (JSOTSup 49; Sheffield: Sheffield University Press 1998) 128.

20 For more, see A.R. Michalak, Angel as Warriors in Late Second Temple Jewish Literature (WUNT 2/330; Tübingen: Mohr Siebeck 2012) 101-107.

21 On early Christian reception of the traditions associated with Michael in the Revelation of John, see D.D. Hannah, Michael and Christ. Michael Traditions and Angel Christology in Early Christianity (WUNT 2/109; Tübingen: Mohr Siebeck 1999) 135, 151-154.

22 The title of an archangel (archaggelos) is not mentioned in LXX; however, an analogical appellation appears in Jewish literature, e.g. in: 1 Book of Enoch 20:8, Book of Jubilees 10:7, Life of Adam and Eve (Apokalupsis Mouseos) 22:1; 37:4, Testament of Abraham 1:4.6; 10:1, and in many other works. The notion of an angel of a higher rank is not always referred to with the term archangel. More on the hierarchy of celestial beings and the various naming conventions to be found in Jewish literature regarding the beings that can be conceived of as archangels, see Michalak, Angels as Warriors, 56-66. 
The angelology of the Second Temple period points to numerous roles ascribed to angelic entities: they were considered to be God's messengers and servants, the carriers of God's revelation, defenders of nations, intermediaries between men and God, ministers in the celestial cult, and beings transporting human souls after death. ${ }^{23}$ No less abundant is the range of functions attributed to Michael. The apocalyptic literature sees him predominantly in the distinctive role he plays for Israel, as the nation's protector and guardian, its advocate before God, and Satan's opponent, the intermediary between the earthly and the celestial cult. Michael was included in the number of angels in God's Presence, able to see the Face of God, as well as those manifesting God's Presence. He was considered to be one of the archangels, he was also assigned a superior position among the archangels and the role of the high commander (archistrategos) of the angelic hosts. ${ }^{24}$ In the Qumran texts, he is presented either as the prince of light, commanding the angelic army and the principal adversary of the prince of darkness or as the guide of the righteous leading them on the paths of justice. ${ }^{25}$ The rabbinic tradition, much like the Christian one, highlighted Michael's role in the eschatological events. ${ }^{26}$

What deserves most attention is predominantly the body of Enochic tradition, for in the later section of his argument the author uses a citation from 1 Enoch $1: 9$, an indication that both for him and for the readers of his epistle it was wellknown literature. In 1 Enoch 10:11-11:2, Michael is one of four archangels, who was entrusted with the tasks of binding until the judgment day of Shemihazah - the leader of the rebellion of angels and those who followed him, as well as their offsprings, and the task of purifying the Earth of iniquity. He is the one who cooperates with God in order to achieve the total triumph over evil. ${ }^{27}$ In 1 Enoch 20:1-8, Michael is one of seven archangels (besides, Uriel, Raphael, Raguel, Sariel, Gabriel, and Remiel), whose task it was to watch over the best part of humanity (1 Enoch 20:5). Thus, he is the patron, defender, and protector of Israel. That role of Michael the Archangel is the most disseminated one in

23 Cf. Hannah, Michael and Christ, 28-32.

24 Cf. Hannah, Michael and Christ, 15-75; Michalak, Angels as Warriors, 99-124. On the function of the angel of Presence and the semantic capacity to determine it, see J.C. VanderKam, "Angel of Presence in the Book of Jubilees," DSD 7/3 (2000) 378-393; M.J. Davidson, Angels at Qumran. A Comparison Study of 1 Enoch 1-36, 72-108 and Sectarian Writings from Qumran (JSPSup 11; Sheffield: Sheffield Academic Press 1992) 195. On the function of the archistrategos, see Hannah, Michael and Christ, 38-40; Michalak, Angels as Warriors, 107-114.

25 Cf. G.W.E. Nickelsburg, 1 Enoch 1. A Commentary on the Book of 1 Enoch, Chapters 1-36; 81-108 (Minneapolis, MN: Fortress Press 2001) 209-210. Hannah, Michael and Christ, 64-75. More on the functions performed by angels, as indicated in the Qumran texts, see the monograph: Davidson, Angels at Qumran.

26 Cf. Hannah, Michael and Christ, 102, 127, 167-168.

27 Cf. Nickelsburg, 1 Enoch 1, 215, 224-226. 
the Jewish tradition. ${ }^{28}$ In 1 Enoch 71:3, Michael the Archangel is the guide of Enoch around Heaven. He reveals to Enoch the mysteries of divine mercy and justice, and the mysteries regarding the end of Heaven.

The persuasive force of such attribution of character traits and functions to Michael proves important from the point of view of the argument presented in the Epistle of Jude, for it introduces a value that the author has not informed his addressees of directly; namely, that Michael the Archangel is also their defender, protector of the faithful, guarding them from the influence of the unjust, and from straying down the path of iniquity. More than a mere historical figure-albeit of honourable ethos and worth example to follow-he is a person who, having been sent by God, performs the entrusted task and whose mission of leading others into the battle against Satan has remained relevant. It assumes particular significance in the context of a call for the readers of the epistle to fight for the faith they received, as it points to the presence and real protection from Archangel Michael, thus additionally enhancing his cogency as a role model.

In order to be able to interpret the wealth of potential connotations, it is vital to refer to the source from which this particular motif of contention between Michael and Satan might have been drawn. Extremely noteworthy in evaluating the author's use of intertextual references in constructing his desired persuasive space would be the analysis of the process of decontextualisation and re-contextualisation, of whether and to what extent he introduces alterations to the motif, as well as the evaluation of how such possible travesty serves the function of reworking the subject and conveying new content (as assumed in the model put forth by V.K. Robbins). It would only be possible, were we in possession of the text that the author had cited from. Regrettably, as already mentioned, we do not know at present the text or the form of the oral tradition he used. The very motif of a struggle between an angel, as an emissary of God, and Satan, as His opponent, seems relatively frequent, and may be found, for instance in the $\mathrm{Da}$ mascus Document (CD) 5:17-18; in the Community Rule (1QS) 3:18-25; in the Visions of Amram 1:10-14 (4Q543-548); in the Testament of Asher 6:4-6; in the Shepherd of Hermas, mainly in Mandate. However, none of the above texts pertains to the contention over the body of Moses. Ancient testimonies point to the text of the Assumption of Moses (known in antiquity as Analepsis Mouseos, Ascensio Mosis, or Assumptio Mosis) as the source for the author of the Epistle of Jude..$^{29}$ Nowadays, the text tends to be identified as a work titled Assumptio Mosis

28 Cf. G.W.E. Nickelsburg, Resurrection, Immortality, and Eternal Life in Intertestamental Judaism (Cambridge, MA: Harvard University Press 1972) 11-15. See also, for instance: Rule of War (1QM) 17; Babylonian Talmud bHagigah 12b; bMenahot 110a.

29 Such mentions in the commentaries to the Epistle of Jude can be found in Clement of Alexandria's Adumbrationes in Epistolam Judae (PG 7,731-734), in Origen's De principiis 3.2.1, and in Gelasius Cizycenus' Historia ecclesiastica 2.17.17. 
or Diatheke Mouseos, Testamentum Mosis, due to the genre it represents. ${ }^{30}$ However, it has not been preserved in its entirety; moreover, none of the manuscripts provides a fragment reflecting the passage in Jude $9 .{ }^{31}$ As indicated in the Introduction, a reconstruction of the potential source text that had major influence on the commentators of the Epistle of Jude was undertaken by R. Bauckham. On the basis of notes, extant texts featuring analogous motifs, and the Christian literature of the later period, he recreated a potential phrasing of a narrative presenting the intervention performed by Michael the Archangel in the case of the burial of Moses, possibly drawn from the final section of the Assumption of Moses or the Testament of Moses. ${ }^{32}$ A critical commentary of The Assumption of Moses by Johannes Tromp introduces revisions to some of Bauckham's proposals, mainly regarding the object and the character of the dispute between Michael and the devil. ${ }^{33}$

Assuming that the text reconstructed by R. Bauckham may be plausible, if not as a written source then as a vehicle of interpretative tendencies associated with the motif, it is worth paying particular attention to the essence of the controversy, and the reason for Michael the Archangel's utterance.

Michael has been sent by God to take the body of Moses from Mount Nebo and bury it in a designated place. This task undertaken by the Archangel is met with opposition from Satan, who denies Moses the right of honourable burial, due to his being a murderer. In fact, however, he wants the people to start worshipping Moses in his own cult. Being obedient to God, the Archangel is able to recognise the wickedness of Satan's intentions, but he submits his opponent's behaviour to God's judgement. At that instance, Satan leaves, and Michael performs the task, as ordered by God. Such a narrative would seem to further highlight what can already be sensed in the author's allusion, to wit: that the crux of the matter lies in the reference to God.

A more balanced proposal put forth by J. Tromp (who is of the opinion that in The Assumption Moses we are able to talk of the occurrence of a dispute between Michael and Satan over the body of Moses, but that we are unable to recreate any details regarding the course of their interaction, nor to discover the root cause of

30 Johannes Tromp (The Assumption of Moses, 119-120, 270) believes the work ought to be included in the number of texts addressing in its discourse the issues of parting, departure, death ("farewell discourse"), in this case, linked to the tradition of the burial place of Moses being unknown, which aligns well with the genre known as testament.

31 On the Testament of Moses and the text's possible relation to the Assumption of Moses, see J.H. Charlesworth (ed.), The Old Testament Pseudepigrapha. I. Apocalyptic Literature and Testaments (New York: Doubleday 1983) 919-926; Tromp, The Assumption of Moses, 115-116.

32 See an exhaustive study, Bauckham, Jude and the Relatives, 235-270, and an older, more concise version of his analyses in a digression in the commentary, Bauckham, Jude, 2 Peter, 65-76.

33 See Tromp, The Assumption of Moses, 270-280. 
the contention between them), ${ }^{34}$ by shifting attention to the actual phrasing of text in Jude 9, reinforces the interpretation according to which the motif was largely influential due to the fact that it presented the motivations behind the assumed attitudes. Of much lesser importance is whether we are dealing with a scene of a burial, or what Satan actually wants to do with the body of Moses, or the fact that he recalls Moses' misdeed in Egypt. What matters is his motivation and his true objective - of opposing God, and hence of inducing idolatry and attributing the Creator's authority to himself - by judging human deeds and pronouncing verdicts pertaining to their fates even after their death.

It is worth noting that the wording of the potential source story only to a small extent sheds light on the particular behaviour of the ungodly criticised by the author of the Epistle of Jude. Since even in the source of the exemplum it proves rather difficult to identify it, we may, first of all, infer that the addressees of the letter were very well aware of it, or that they did not understand the extent of shamelessness of behaviour of those in their community referred to by the author as godless. For that reason, the author's argument focuses on the choice of such an example that would enable his readers to identify the actual problem and motivate them to defend their faith appropriately to the situation. The other probability is that the author's indictment is of a general nature and in no way intends to stigmatise any specific behaviours or beliefs (even though it was such particular situations that gave rise to the argumentation), but only to establish what lies at their root.

Among the intertextual references, one should not ignore the text from the Book of Zechariah 3:1-2, which could activate strong associations in the addresses regardless of the source text, and operate in line with the persuasive intent of the author of the Epistle of Jude, mainly due to the motif of the words directed at Satan. ${ }^{35}$ In the fragment, Satan takes on the role of an accuser, but we do not find any words he utters in the text. The reader receives that information from the narrator. The figure of the messenger has most of all the function of

34 See Tromp, The Assumption of Moses, 275.

35 Cf. R.L. Webb, "The Use of 'Story' in the Letter of Jude: Rhetorical Strategies of Jude's Narrative Episodes," JSNT 31/1 (2008) 59. Johannes Tromp (The Assumption of Moses, 273) is of the opinion that the Epistle of Jude may pertain to an already reworked motif drawn from The Assumption of Moses, and not directly to the Book of Zechariah. However, there seem to be no grounds to assume that the text of Zech did not have any influence on the readers and only asserted itself in the reception of the passage in The Assumption of Moses. The fact that the motif of judgement drawn from Zech was used in another text confirms its persuasive value and ability to influence the addressees regardless of the intention of the epistle's author. 
executing the commands of JHWH, he is attributed the role of an advocate and a witness in the trial of Joshua. ${ }^{36}$

What is of particular interest for us in that scene, is the utterance directed at the accuser. It comprises two sentences, which — though of different structureare parallel to one another. These repeat the formula "the Lord rebuke you" that sounds like words of an exorcism and did in fact assume that meaning at a later period (cf. bBerakhot 51a). ${ }^{37}$ The word $g^{\prime} r$ used here indicates an intense, at time violent, activity. God, who forbids Satan to act, thus changes and inverts his intentions-makes Joshua pure. ${ }^{38}$ The structure of that formulation is clear: the preposition before the demonstrative pronoun "you" unequivocally identifies the object of the command. The repeated combination comprising the preposition, the verb (either as a jussive or an indicative form), and the demonstrative pronoun serves an emphatic function for the entire utterance and makes it sound like a judicial pronouncement of a verdict. ${ }^{39}$ Slightly more complicated proves the question of who is saying it. The great majority of translations and commentaries are dominated by the view that the sentence is uttered by the messenger on behalf of God. However, the verb $g^{\prime} r$ appears frequently in contexts when YHWH reprimands those acting against Him and the enemies of Israel (see, for instance, Isa 17:13; Ps 9:6; 119:21), and He is always the subject of the action Himself. The use of such a specific manner of speaking about oneself in the third person may occur precisely in formalised texts, that is why the formula "YHWH rebukes you / YHWH forbids you Satan" may actually be pronounced by God. ${ }^{40}$ This potential ambiguity is very striking and may emphasise that even if it is God's messenger speaking, his words are identical to those uttered by God, who sent him.

Now, referring the above to the exemplum from Jude 9, the words spoken by Michael to the devil may be perceived as identical with God's will, and that in turn would highlight both Michael's obedience and Satan's opposition to God, further reinforcing the ethical (ethos) aspect of the argumentation (taking Mi-

36 Some scholars point to the judicial character of the episode and strive to uncover the historical background of the text. There is no mention within it of the direct reason for such a trial, but God's promises prompt us to assume that, firstly, the accuser considered Jerusalem to be not worthy of being the venue of a cult, and the archpriest not worthy of performing the cultic duties. Cf. C.M. Meyers - E.M. Meyers, Haggai. Zechariah 1-8. A New Translation with Introduction and Commentary (Garden City, NY: Doubleday 1987) 183-186.

37 Cf. A. Wolters, Zechariah (HCOT; Leuven: Peeters 2014) 92.

38 Cf. C. Stuhlmueller, Rebuilding. A Commentary on the Books of Haggai and Zechariah (Grand Rapids, MI: Eerdmans - Edinburgh: Handsel Press 1988) 78.

39 The analogy to Psalm 109:6, with its request for the accuser (Satan) to stand on the right so that his guilt be judged, is a clear-cut reference to the judiciary; hence, we may assume that also in the Book of Zechariah the vision presents Joshua on a trial before a court. Cf. D.L. Petersen, Haggai and Zechariah 1-8. A Commentary (Philadelphia, PA: The Westminster Press 1984) 189.

40 Cf. Wolters, Zechariah, 91-93. 
chael as a role model is honourable). It also fits in very well with the content of the source story, corroborating the powerful impact of the words in that formula, that stems from the Archangel's attitude before God. In that narrative, it thwarts the intentions of Satan, too-after the words spoken in the dispute, he backs down, and the Archangel fulfils God's will.

Moreover, an important facet of the episode in Zech 3:1-2 is God's Presence, within which the entire dispute takes place. In the exemplum of Jude 9, the author does not clarify the matter directly; we do not know whether it was expressed openly in the potential source text. However, even the very words spoken by the Archangel point to Lord's Presence; additionally, the fact is presupposed by the intertextual references to other traditions, that attributed the role of the Angel of Presence to Michael, as discussed above. Thus, in a rather natural manner, through the use of analogy, it reminds the addressees that whatever concerns them and the ungodly men in their community occurs in God's Presence and is judged by Him. Such an intertextual connotation, therefore, lends still more weight to the author's argumentation, rendering the actions of the wicked willing in any way to question God's authority as absurdly futile.

\section{The Motif of Archangel Michael in Light of Social and Cultural Categories}

In the thesis presenting the case (Jude 3), and in the display of his view on the matter in propositio (Jude 4), both of which are to be supported by the argument in Jude $9,{ }^{41}$ what transpires is the situation of a crisis within the community. The call for the addressees to fight for their faith and author's opposition to the attitude represented by the wicked men in the community, particularly their questioning of the authority of the Lord, Jesus Christ, makes us want to analyse the argumentation in Jude 9 from the point of view of the so-called game of honour and the patron-intermediary-client relationship, as the key categories governing the social relations in the culture of the period, influencing the adoption of specific attitudes and behaviours.

41 Both in the analyses of the work's structure in terms of the theory of rhetoric and the theory of epistolography, verses 3 and 4 of the Epistle of Jude are considered to be the moment when the cause and the purpose of the letter are divulged, or, in other words, when the thesis and the proposal of argumentation are unfolded. Cf., for instance, B. Reicke, The Epistles of James, Peter, and Jude. Introduction, Translation, and Notes (Garden City, NY: Doubleday 1964) 193; D.J. Moo, 2 Peter and Jude (NIV Application Commentary; Grand Rapids, MI: Zondervan 1996) 29; Davids, The Letters, 23; D.F. Watson, Invention, Arrangement, and Style. Rhetorical Criticism of Jude and 2 Peter (Atlanta, GA: Scholars Press 1988) 77-78; Green, Jude and 2 Peter, 52. 


\subsection{The Patron-Client Relation and the Category of Grace in Jude 9}

In a society representing the Mediterranean culture of the New Testament era, the important principles governing the establishment of social relationshipsboth in the familiar and in the wider, business and political circles-included patronage, friendship, the principles of utility and mutuality, honour and shame, and that of grace as superior to all the above. ${ }^{42}$ The institution of patronage, and of vassalage associated therewith, constituted a relationship of interdependence between two parties, of which the one enjoying the higher status performed the function of a patron, whereas the other one of a client, who, however, should not be reduced to that of a recipient of benefits. ${ }^{43}$ Either side of such a relationship had their obligations to the other, and both were in some way mutually dependent, albeit not on equal standing, for the role of a patron assured their advantage in such relations and provided them with the initiative function. The patronage-clientage are founded on the expected respect for honour, a means of legitimising the social order. ${ }^{44}$ The main principle constituting and maintaining patron-client relationships was above all their utility, while secondarily mutuality, with its typical expression in the form of, on one hand, authority and the ability to act (patron), while on the other, of submission to it (client). ${ }^{45}$

Let us now consider the aspects that are significant in understanding these connotations in the interpretation of the motif of Michael the Archangel, we are interested in.

Already in the form of address in the Epistle of Jude, we observe the phrasing presenting it as socially embedded in the culture of the period; the underlying relation schema is as follows: the Father and Jesus Christ take the role of a Patron, whereas the addressees of the epistle and its author remain in the relation of vassalage to Them. It is the Father and Jesus who have the initiative and the prerogative to act, whereas the addressees are the recipients of that activity. ${ }^{46}$

42 Cf. R.P. Saller, Personal Patronage Under the Early Empire (Cambridge, UK: Cambridge University Press 1982) 7-26.

43 More on the interdependence between both sides of the relationship, see, for instance: A. Drummond, "Early Roman Clients," Patronage in Ancient Society (ed. A. Wallace-Hadrill) (London: Routledge 1989) 89-115; J.H. Elliott, "Patronage and Clientage," The Social Science and New Testament Interpretation (ed. R.L. Rohrbaugh) (Grand Rapids, MI: Baker Academic 1996) 144-155.

44 Cf. E.C. Stewart, "Social Stratification and Patronage in Ancient Mediterranean Societies," Understanding the Social World of the New Testament (eds. D. Neufeld - R.E. DeMaris) (London - New York: Routledge 2010) 204-206. On the role of honour in the patron-client relationship, see, for instance: J. Kręcidło, Honor $i$ wstyd w interpretacji Ewangelii. Szkice z egzegezy antropologicznokulturowej (Lingua Sacra. Monografie 1; Warszawa: Verbinum 2013) 41-42.

45 Cf. J.J. Pilch - B.J. Malina, Biblical Social Values and Their Meaning. A Handbook (Peabody, MA: Hendrickson 1993) 133-134.

46 Cf. Green, Jude and 2 Peter, 46-48. 
The structure of thinking and expressing oneself in terms of the patron-client relationship becomes more apparent in the proposal of taking the command (Jude 4). This verse attributes Jesus Christ with authority and lordship, the qualities of a patron. The author of the epistle stands strongly against those denying this fact. Because of the fullness of His authority, Jesus is seen here not as a delegated broker, performing the patron's duties, but as the Patron Himself. This way, the divine identity of Jesus is conveyed to the readers. ${ }^{47}$ God is perceived as the Only One to fully control all resources and their distribution, possessing the authority over time and range of involvement of anyone in the sphere of His patronage. ${ }^{48} \mathrm{In}$ Jude 4, God is shown as the dispenser of grace, and that reaches beyond a mere patron-client relationship. "Grace" (charis) is considered to be a separate category in anthropological research, distinguished as particularly important in the culture of the Mediterranean. ${ }^{49}$ One may discuss the various ways it was manifested and granted, both in the realm of the sacred and of the profane. A patron was not obligated to extend grace, though he could manifest it to his clients, but not only to them. Extending one's grace to those not bound by the patron-client relationship and not placed in the orbit of patron's influence, was a testament to the beneficiaries' independence..$^{50}$ God-while being a patron-is much more than just a patron. He is presented in terms of a selfless Benefactor, a quality more typical for familial relationships, rather in bonds of friendship than of the patronage-clientage framework. Extending one's grace consisted in bestowing gifts surpassing the margins of limited goods.

In the patron-client relationships, "grace" could be extended mutually, although in line with the principle of such relations - not in an equal manner. The same term (charis) denoted the gratitude expressed by the client for the grace extended to him by the patron. The answer of gratitude on the part of the client was obviously not considered to be equal to the grace received. A gift of grace constituted a deed exceeding ordinary way of expressing friendliness, and above all it was devoid of any burden of being vested in any interest. What is more, it often involved the patron incurring certain — not merely financial—costs without expecting to ever be paid back or reciprocated in any other way. For the essence of a gratuitous gift from the sphere of the sacred was transferred to the realm of the profane. Within the former, the donations given out of grace by

47 Cf. Moo, 2 Peter and Jude, 231.

48 More on the subject in the monograph: J.H. Neyrey, Render to God. New Testament Understandings of the Divine (Minneapolis, MN: Fortress 2004).

49 Cf. J.A. Pitt-Rivers, "The Place of Grace in Anthropology," HAU 1/1 (2011) 423-450. [Reprint from J.A. Pitt-Rivers, "Postscript: the place of grace in anthropology," Honor and Grace in Anthropology (eds. J.G. Peristiany - J.A. Pitt-Rivers) (Cambridge, UK: Cambridge University Press 1992) 215-246].

50 Cf. Pilch - Malina, Biblical Social Values, 83-88. 
the deity surpassed all the earthy sacrifices and stemmed entirely from the will of gods. The acts of grace in the patron-client relationship included, for instance, the liberation from slavery, the assistance in paying off slavery, debt forgiveness or payment, a surety in court resulting in a pardon, or protecting one's honour, etc. The crucial element in extending grace was that such a gift ought not to be associated with the necessity of being paid back, for such motivation would have been considered interest-oriented, and hence appropriate for a service paid according to the principle of utility. On the other hand, a failure to express gratitude on the side of the person who received the gift was considered reprehensible, even though much like the act of good-will it was entirely voluntary. Already the acceptance of such a gratuitous gift was seen as the basic expression of gratitude. ${ }^{51}$

Using the criteria of the patron-client relationship, and the category of grace to the episode presenting the contention between Michael the Archangel and the devil over the body of Moses requires the predefined roles to be attributed.

As demonstrated in the analysis of the exemplum constructed by the author of the epistle, God, even though he is not an active participant in the narrative, is present therein through the reference to Him contained in Michael's utterance directed at the devil. Precisely due to those words we are able to recognise that God is indubitably attributed with the role of the Sovereign, possessing the power to decide, set the rules, indicate intermediaries, grant benefices, and extend His grace to whomever he wishes.

Michael the Archangel acts as God's client, mediating in the case of Moses. $\mathrm{He}$ is the executor of Sovereign's will regarding Moses and as such he is entirely subordinated to God in terms of the methods of fulfilling the task he was entrusted with. Thus, he is a client-broker responsible for carrying out the patron's interests. ${ }^{52}$ The enforcement of God's command with regard to Moses may be interpreted as an act of protecting the honour of God-Patron, who used the service of an intermediary possessing a higher status than Moses.

Moses, too, may be considered to be God's vassal, someone within the domain of God-Patron's protection. The particular solicitude of the Patron also when the client has already expired, in the case of Moses' burial, may additionally be seen as a reward for the satisfactory completion of his function as a broker (intermediary, attorney) of God among the chosen people, he was sent to. Hence, Moses could be perceived as someone performing similar functions to those of

51 Cf. D.A. deSilva, Honor, Patronage, Kinship and Purity. Unlocking New Testament Culture (Downers Grove, IL: Intervarsity 2000) 104-113; J.H. Neyrey - E.C. Stewart (eds.), The Social World of the New Testament. Insights and Models (Peabody, MA: Baker Academic 2008) 51-56.

52 More on the function of a broker and the institution of an intermediary, particularly the intermediaries of God, see, for instance: A. Batten, "Brokerage: Jesus as Social Entrepreneur," Understanding the Social World of the New Testament (eds. D. Neufeld - R.E. DeMaris) (London - New York: Routledge 2010) 217-219. 
Michael, but in a scope determined for him by God. The story could then be interpreted according to the principle of grace, or that of mutuality.

The addressees of the epistle can identify with the vocation of Moses. Though clients in their relationship with God-Patron, they also perform the tasks of brokers before those who Gods sends them to and have the duty of executing these task in full conformity with God's will, just like Moses, but even more so like Michael, regarding whose stance there are no reservations. The illustration of God's acts towards Moses in Jude 9 also constitutes a reference to the judicial issues introduced along with the propositio in Jude 4 and surfacing throughout the epistle's argumentation. God as patron reserves the right to judge and pronounce the verdict as his will dictates. That will with regard to those holding on to their attitude of opposition to God, the wicked, is apparent, as instantiated by the author in Jude 5-7. Whereas the readers are to keep waiting for God's grace (Jude 21), and they may expect on the day of the coming judgement merciful protection adequate to that extended to Moses by God-Patron. ${ }^{53}$

In light of the likely source story, God's role of a Benefactor extending His grace to Moses, instead of merely performing the duties of a Patron, becomes ever more obvious. The sin of murder that Moses is accused of by Satan did not deprive him either of God's protection, or of an honourable burial according to the intention of the One who had sent him. God knew his client-broker, but he showed him His grace, pardoning him the crime of murder and liberating him from the verdict and dishonour. As opposed to Michael, who fully embraces God's clemency and becomes its articulator, Satan attempts to alter God's grace. Michael, entirely subordinate to God, participates in the grace extended to Moses. His firm reaction to Satan's accusations against Moses serves as another piece of substantiation of Michael's identification with God's will.

Satan appears to be in opposition in all these three aspects. He does not take a stand against God directly, nor does he negotiate with Him; hence, he is aware of God's higher status. He enters into negotiations with Michael, meaning that he acknowledges his position of God's intermediary. The act of Michael's submitting Satan to God's judgement indicates that Satan is dependent of God and that it is God who has the power, but Satan does not assume the role of a client in their relationship. He attempts to take over the role of the patron (as a rival), but that pertains mostly to Moses, but not to Michael, and least of all to God. Satan's behaviour indicates that he refuses being dependent on God and strifes to challenge Him, trying to question his decision and the grace extended to Moses, but the range of his influence is limited. Unable to take over God's position, he surrenders after Michael's words asking for God's judgement of Satan. Nor is

53 Cf. A. Chester - R.P. Martin, The Theology of the Letters of James, Peter, and Jude (Cambridge, UK: Cambridge University Press 1994) 77-79. 
he able to gain control of the position of Michael as God's broker, for he would then have to accept complete subordination to God as the only Sovereign. His challenge against God's will makes him look ridiculous.

\subsection{The Challenge of Honour and the Riposte (Challenge-Response)}

In contemporary anthropological and cultural research, honour and shame are considered to be the central values of the Mediterranean culture, pointing to the coherence of that culture. They are seen as dynamic values, undergoing change both in time and space, remaining the key factors shaping social relations in the region. ${ }^{54}$ Therefore, it is an important category worth taking into account in New Testament research.

The challenge-response of honour belongs to the permanent sphere associated with honour and dishonour, with the requirement of its constant reaffirmation in public confrontations, ${ }^{55}$ when honour is conceived of in terms of precedence and conflict with the deity, when it is regarded as a virtue and constitutes an element of self-esteem (of an individual and a group). ${ }^{56}$

Using the model of social and cultural analysis, we may see the answer to the challenge of honour as a significant feature of the Epistle of Jude.$^{57}$ The issue is, therefore, to determine whose honour is at stake here, who poses the challenge to whom, and the type of that challenge, what is its object, the response to it, and its eventual result.

The scene of the dispute between Michael the Archangel and the devil fits in perfectly with the situation of a challenge of honour. It is Satan who assumes the role of a challenger. That initiates the game of honour here. Archangel Michael is the one responding. According to the model developed by Bruce J. Malina, a challenge posed to someone of higher status was seen as an insult to their honour and required to be punished. For a game of honour could only involve peers or occur through intermediaries. ${ }^{58}$ By accepting these assumptions, we are

54 Cf. S. Bussata, "Honour and Shame in the Mediterranean," Antrocom $2 / 2$ (2006) 75-78. In her paper, the author reviews and evaluates the research performed in the field over the last three decades. An assessment of the respective proposals regarding honour and shame in anthropological research and the directions for further development in relation to a model of interpretation of biblical texts in light of the above values put forth by Bruce J. Malina can be found in Kręcidło, Honor $i$ wstyd, 25-80.

55 Cf. Z. Crook, "Honor, Shame, and Social Status Revisited," JBL 3 (2009) 591.

56 The distinction was introduced by L.J. Lawrence, "“For Truly, I Tell You, They Have Received Their Reward' (Matt 6:2). Investigating Honor Precedence and Honor Virtue," CBQ 64 (2002) 687-702.

57 Cf. J.H. Neyrey, 2 Peter, Jude. A New Translation with Introduction and Commentary (AB 37C; New York: Doubleday 2004) 31-32, 51-52.

58 These assumptions have been subjected to criticism. Zeba Crook ("Honor," 602-604) demonstrated that the game of honour pertained to all levels of relationships, including the human-deity relationship. 
able to specify that Satan does not directly challenge God, but the Archangel, for it is with the latter that he enters into a relationship, even though it actually is a challenge posed to the honour of God, due to the fact that it is God's and not Michael's decision regarding Moses that Satan is attempting to overrule. The fact that Archangel does accept the challenge indicates that he considers Satan's status to be equal to his own, but also that as God's intermediary/broker he retorts to the challenge in defence of His honour.

The response occurs on two levels. The first involves the verbal reaction in the form of the answer subjecting Satan to God's judgement. We may read it as a natural consequence of the realisation that Satan has in fact attacked the honour of God and therefore should be punished, a decision to be taken only by someone of a higher status, whose honour has been subjected to public evaluation. The verbal riposte may also be considered in terms of a challenge posed to Michael, a challenge negating his honour as a broker. For it is the reaction of Archangel, and it is firm and specifically defined. Michael enters into the dispute with Satan regarding Moses, that is he accepts the challenge and presents an intended solution. As a form of defence of his own honour, he uses a reference to the One who sent him on a mission. The other level of Archangel's riposte is his attitude (hence, something more than a mere verbal reaction) of complete obedience to God's plans and commands.

That the Archangel entered into a dialogue with Satan, i.e. that he accepted the challenge, in no way proved advantageous for Satan. He did not manage to violate God's honour, as Michael did not in the least fail to execute His commands, and hence did nothing that could in any way be seen as undermining God's prerogatives. That would have been the case, had Archangel Michael entered into polemics, pursued his rights, or allowed himself to assess and pronounce the verdict on Satan's behaviour. That way, he would have been drawn into a game aimed at subverting God's authority and power. Michael did accept the challenge, but he answered it according to the rules set by God, and not according to the standards that Satan attempted to impose on him.

Ultimately, the challenge posed by Satan is presented as entirely ungrounded. Obviously, a fundamental party in the public evaluation of the challenge and riposte, i.e. the final effect of this "game," are the addressees of the Epistle of Jude. The conclusion drawn from the example presented by the author of the letter should be straightforward - the challenge of Satan proved inefficient, God's honour and authority have been confirmed, owing to the appropriate response given by Michael the Archangel.

In what way does the example in Jude 9, seen from the point of view of a game of honour, pertain to the thesis that it constitutes a supporting argument for?

In the thesis (Jude 3), the author of the Epistle of Jude instructs his readers that as a community they ought to accept the challenge they were faced with. 
The necessity of an agonistic struggle for honour is manifested in the call for them "to contend for the faith that was ... entrusted to all the saints." First of all, it means that the confrontation at hand is not a positive one ${ }^{59}$ i.e. that the members of the challenging party do not wish to be granted a share in the honour of community; secondly, that the honour of the entire community has been put to the test that cannot be left without a firm answer.

The subject of the challenge is therefore the faith they were entrusted with, and hence a very specific deposit of faith and everything associated with and stemming from it. The addressees as the heirs of the deposit have become "saints" themselves. Thus, we are not dealing with acquired honour, but with ascribed honour, that they are the heirs of, analogically to the honour inherited by blood ties. Their sanctification results from their having been incorporated into the mystery of God's sanctity. They were purchased by the blood of Christ and included in God's family, in which they participate through the grace of faith they have been granted. ${ }^{60}$ The struggle for precisely such faith is then a necessity, for the challenge undermines the honour of the entire family: above all the honour of God, who wanted them to participate in His reverence; their own honour, as the chosen heirs; as well as the honour of all that who alongside the addressees share in the gift, by establishing a new community - the Church. In order for the latter community to preserve the honour of God's family, it has to follow the principles outlined and demonstrated by Jesus Christ. Hence, the readers do possess the honour ascribed to them, but to maintain it they are required to make efforts, just like all other members of God's family, purchased by the blood of Christ, do. He defines and establishes the standards of behaviour. Abiding by those principles, therefore, constitutes an incessant confirmation of the acceptance of the gift of participation in the honour of God Himself. As such, it becomes an endeavour analogical to that required to secure the honour publicly verified in the game of honour. ${ }^{61}$

A failure to confront the challenge posed by the wicked members of the community is equivalent to agreeing to have their honour, attributed to them by God, questioned. For no answer given to the challenge of honour was also seen as an answer. It proved particularly important in the case of a negative challenge, when the absence of reaction on the part of the challenged party was considered to have meant submission and the loss of honour to the benefit of the challenger. ${ }^{62}$

59 On positive and negative challenges of honour, see, for instance: B.J. Malina, The New Testament World. Insights from Cultural Anthropology, 3 ed. (Louisville, KY: Westminster John Knox Press 2001) 34, 40-42.

60 Cf. D.J. Rowston, "The Most Neglected Book in the New Testament," NTS 21 (1975) 559.

61 Cf. Crook, "Honor," 598-599.

62 Cf. Malina, The New Testament World, 35. 
The author demonstrates to his addressees the elements of honour, associated with the faith they had been entrusted with, that the challenge posed by the wicked pertains to. It is their objecting to the rule and lordship of Jesus Christ, attributed exclusively to Him, and their transforming the grace they received into lasciviousness. Therefore, it is more than a mere verbal discussion, undermining the basic tenets of participation in God's honour, but also deeds contrary to the order of its existence and of desired manner of its operation. Hence, the lack of respect for the authority may also be associated with particular deprecation of the pastoral duty of those responsible for the community, who perform it according to the mission entrusted to them by God..$^{63}$ In light of the fact that the author of the Epistle of Jude defines the challenge at hand, markedly underscoring that the faithless in fact attack God himself, there can only be one conclusion, that the addressees had not been aware of it. ${ }^{64}$ They might have felt a sense of infringement of their honour as a community, of the way of life and the values they hold dear, but it was not an obvious matter. The text of the letter suggests that they had taken no action against it, as if oblivious to the necessity of public affirmation of the honour ascribed to them; moreover, they could also ignore the fact that the behaviour of people the author of the epistle referred to as the ungodly, does not meet the standards of honour of the family they belong to. Perhaps, to some extent, they accepted the behaviours displayed by the wicked of their community, through their lack of reaction, granting them the status of honourable demeanour. It is also possible that they considered ignoring the challenge to be the proper manner of responding to it, being convinced of the honour attributed to them by Jesus Christ.

Neither could it be ruled out that the wicked, much like the rest of their community, invoked the honour attributed to them by the sacrifice of the blood of Jesus Christ, assuming that their incorporation into the family of God entitled them to create the rules to govern its life. That, however, would amount to willingness to take the place reserved for the Patron-Father of the family, thus depriving Him of His honour - an absurd development that ought to have been met with a strong reaction of other members of the community. It seems more likely that the "godless" constituted a group that built their honour on the basis of their own charismatic experiences, and the challenge consisted in their demand that the community accept their achieved honour, thus leading to the situation when their actual motivation of those actions was disregarded by the community. ${ }^{65}$

The fact that the ungodly turn God's grace into promiscuity meant that their behaviour violated the generally accepted norms. It may have been seen in terms

63 Cf. Neyrey, 2 Peter, Jude, 52.

64 Cf. D.E. Hiebert, "An Exposition of Jude 3-4,” BSac 142 (1985) 145.

65 Cf. Neyrey, 2 Peter, Jude, 48. 
of open transgression and rejection of what the other members of the group considered of the highest value.$^{66}$ It also constituted an infringement of the order, as it negated the role of God as their Sovereign, who willfully granted His grace and redeemed people, purchasing their freedom at the highest price and requesting nothing in return, besides a firm embrace of the gift. By opting for lasciviousness, the wicked fall into bondage and are willing to establish this state as the standard for the group's behaviour, even if it would boil down to mere toleration of their beliefs and actions. However, by instituting their own rules, they deny the authority of Jesus Christ and pervert - reject even - the gift of true freedom they had been granted by God's graciousness, a gift they had earlier agreed to receive ${ }^{67}$ Their attitude is analogous to that of Satan according to the example in Jude 9. Their challenge to the honour of the community by rejecting authority suggests that they are attempting to acquire the honour of the group's patron, that they demand their rules to be deemed equally worthy of honour, thus willing to become the patron able to include others in the sphere of their honour. ${ }^{68}$

Thus, the call to fight for such faith as had been entrusted to the addressees amounts to the community's riposte to the challenge posed by the godless, and ought to be an open and consistent commitment to the honour they had been attributed, the honour stemming from the dignity of God Himself.

The argument in Jude 9, and above all the manner that Michael answers to Satan's challenge, accords with the programme of communal response to the challenge posed to God, which must be publicly rectified. Having been faced by the wicked, they should assume an attitude analogous to that represented by Michael the Archangel. ${ }^{69}$ Their reaction must be unambiguous and decisive, but at the same time completely based on being obedient and faithful to Jesus Christ. The preservation of His teaching, obedience to His will, imitation of His behaviour constitute the only appropriate response to the challenge posed by the wicked, for it was exactly the rejection of those that served as the foundation for the denial of the honour of God and of the Church.

The resemblance of Michael the Archangel's attitude may also be discerned in the answer provided by the author of the Epistle of Jude, who accepts the challenge. His first riposte is the letter, in which he lays bare the true motivation of the godless, thus engaging the community in the "game of honour." In his letter, he is able to demonstrate the groundlessness of their demand that their behaviour

66 Cf. S.J. Joubert, "Language, Ideology, and the Social Context of the Letter of Jude," Neot 24/2 (1990) 346.

67 Cf. M. Desjardin, "The Portrayal of the Dissidents in 2 Peter and Jude. Does It Tell Us More About the 'Godly' than the 'Ungodly'?,' JSNT 30 (1987) 97-98.

68 Cf. Green, Jude and 2 Peter, 83.

69 At the lexical level, in the Epistle of Jude Michael is juxtaposed against the group referred to as houtoi. Cf. J.D. Charles, "Literary Artifice in the Epistle of Jude," ZNW 82 (1991) 114. 
be considered appropriate for the honour of God's family. He stands in defence of the honour of God, demonstrating that the behaviour of the ungodly will eventually be verified by the authority of Jesus Christ, the sole person to have been granted the right to judge and pass verdicts, analogically to how the story ended for others who dared to undermine God's power before.

\section{Conclusion}

In the presented study, we have analysed - using socio-rhetorical textual analyses - a single reference to external sources by the author of the Epistle of Jude, evoking in his argument the motif of Michael the Archangel.

The author, presenting the exemplum with the motif of contention between Archangel Michael and Satan, constructs a sophisticated persuasive strategy. Firstly, by weaving a positive example into his argumentation based on criticism, he makes his addressees aware of the evil inherent in the attitude of the wicked, by using the technique of rhetorical amplification. The exemplification of Michael's behaviour is a juxtaposition to the examples drawn from tradition in order to highlight the consequences of betraying God and to the attitude of the ungodly members active in the community. The contrast introduced by that motif serves to warn the readers against the results of the behaviour of the godless, and to discourage the addressees from accepting such behaviours. The author does not limit his argumentation to mere discouragement, as the exemplum using the motif of Michael the Archangel constitutes a positive role model. It accords with the rhetoric of advising what is appropriate, and the demeanour displayed by Archangel Michael is definitely worth imitating.

The power of ethos as the crucial factor in the advisory rhetoric is reinforced by the connotation stemming from the interpretative tradition of the Archangel. The analysis of intertextuality of the motif indicates - regardless whether or not the source story that the motif had been drawn from a source the addressees were familiar with - that the possibility of positive influence on the readers was not confined. Universal reception of the figure, based on the Bible, oral tradition, and extra-canonical literature exposed the qualities of the Archangel's complete submission to God, that his functions of leadership, protection, and advocacy resulted from.

The key categories for the Mediterranean of the first century AD, selected in order to analyse the motif and discover the mechanisms driving the discourse of the Epistle of Jude, allowed us to acknowledge the importance of the manner of perceiving the reality, understating the situation of the community, and the factors at its foundation, determining its behaviour and identity. The features characteris- 
tic for social structure in terms of the patron-client relationship, and the category of grace, exhibit an order of dependence of the Christian community, the order in which God is the sovereign Benefactor, the addressees - the beneficiaries of His grace, thus raised to the rank far surpassing that of clients, who only draw profits from their loyalty towards the patron. The motif of Michael the Archangel helps them to become aware of their own position as God's brokers, who are entrusted specific tasks to be performed, and equipped with everything they need and more in order to fulfil their missions. The mechanism associated with the categories of honour and shame, challenge and response, proves crucial to understand the character of the riposte demanded from the addressees. The argumentation with the motif of Michael the Archangel seen against this background clearly, by analogy, indicates that the community should accept the challenge it had been faced with and that the answer requires the attitude of submission to God and of humility.

\section{Bibliography}

Batten, A., "Brokerage: Jesus as Social Entrepreneur," Understanding the Social World of the New Testament (eds. D. Neufeld - R.E. DeMaris) (London - New York: Routledge 2010) 167-177.

Bauckham, R., Jude and the Relatives of Jesus in the Early Church (Edinburgh: Clark 1990).

Bauckham, R., Jude, 2 Peter (WBC 50; Grand Rapids, MI: Zondervan 1983).

Brosend, W.F., James and Jude (Cambridge, UK: Cambridge University Press 2004).

Bussata, S., "Honour and Shame in the Mediterranean," Antrocom 2/2 (2006) 75-78.

Charles, D.J., "Literary Artifice in the Epistle of Jude," Zeitschrift für die neutestamentliche Wissenchaft 82 (1991) 106-124.

Charlesworth, J.H. (ed.), The Old Testament Pseudepigrapha. I. Apocalyptic Literature and Testaments (New York: Doubleday 1983).

Chester, A., - Martin, R.P., The Theology of the Letters of James, Peter, and Jude (Cambridge, UK: Cambridge University Press 1994).

Crook, Z., "Honor, Shame, and Social Status Revisited," Journal of Biblical Literature 3 (2009) 591-611.

Davids, P.H., The Letters of 2 Peter and Jude (Grand Rapids, MI: Eerdmans 2006).

Davidson, M.J., Angels at Qumran. A Comparison Study of 1 Enoch 1-36, $72-108$ and Sectarian Writings from Qumran (Journal for the Study of the Pseudepigrapha Suplement Series 11; Sheffield: Sheffield Academic Press 1992).

deSilva, D.A., Honor, Patronage, Kinship and Purity. Unlocking New Testament Culture (Downers Grove, IL: Intervarsity 2000).

Desjardin, M., "The Portrayal of the Dissidents in 2 Peter and Jude: Does It Tell Us More About the 'Godly' than the 'Ungodly'?," Journal for the Study of the New Testament 30 (1987) 89-102.

Drummond, A., "Early Roman Clients," Patronage in Ancient Society (ed. A. Wallace-Hadrill) (London: Routledge 1989) 89-115. 
Elliott, J.H., "Patronage and Clientage," The Social Science and New Testament Interpretation (ed. R.L. Rohrbaugh) (Peabody, MA: Hendrickson 1996) 144-155.

Fowler, J.D., Theophoric Personal Names in Ancient Hebrew. A Comparative Study (Journal for the Study of the Old Testament Supplement Series 49; Sheffield: Sheffield University Press 1998).

Green, G.L., Jude and 2 Peter (Baker Exegetical Commentary on the New Testament; Grand Rapids, MI: Baker Academic 2008).

Hannah, D.D., Michael and Christ. Michael Traditions and Angel Christology in Early Christianity (Wissenschaftliche Untersuchungen zum Neuen Testament 2/109; Tübingen: Mohr Siebeck 1999).

Hiebert, D.E., “An Exposition of Jude 3-4,” Bibliotheca Sacra 142 (1985) 142-151.

Joubert, S.J., "Facing the Past. Transtextual Relationships and Historical Understanding in the Letter of Jude," Biblische Zeitschrift 42 (1998) 56-70.

Joubert, S.J., "Language, Ideology, and the Social Context of the Letter of Jude," Neotestamentica 24/2 (1990) 335-349.

Kee, H.C., "The Terminology of Mark's Exorcism Stories”, New Testament Studies 14 (1968) 232-246.

Kręcidło, J., Honor i wstyd w interpretacji Ewangelii. Szkice z egzegezy antropologiczno-kulturowej (Lingua Sacra. Monografie 1; Warszawa: Verbinum 2013).

Lausberg, H., Handbook of Literary Rhetoric. A Foundation for Literary Study (Leiden - Boston, MA - Köln: Brill 1998).

Lawrence, L.J., “'For Truly, I Tell You, They Have Received Their Reward' (Matt 6:2). Investigating Honor Precedence and Honor Virtue," Catholic Biblical Quarterly 64 (2002) 687-702.

Malina, B.J., The New Testament World. Insights from Cultural Anthropology, 3 ed. (Louisville, KY: Westminster John Knox Press 2001).

Meyers, C.M. - Eric, M.M., Haggai. Zechariah 1-8. A New Translation with Introduction and Commentary (Garden City, NY: Doubleday 1987).

Michalak, A.R., Angel as Warriors in Late Second Temple Jewish Literature (Wissenschaftliche Untersuchungen zum Neuen Testament 2/330; Tübingen: Mohr Siebeck 2012).

Mickiewicz, F., List Świętego Judy. Drugi List Świętego Piotra (NKB.NT 18; Częstochowa: Edycja Świętego Pawła 2018).

Moo, D.J., 2 Peter and Jude (NIV Application Commentary; Grand Rapids, MI: Zondervan 1996).

Muddiman, J., "The Assumption of Moses and the Epistle of Jude," Moses in Biblical and Extra-Biblical Traditions (eds. A. Graupner et al.) (Beihefte zur Zeitschrift für die Alttestamentliche Wissenschaft 372; Berlin: De Gruyter 2007) 169-180.

Neufeld, D. - DeMaris, R.E. (eds.), Understanding the Social World of the New Testament (LondonNew York: Routledge 2010).

Neyrey, J.H. - Stewart, E.C. (eds.), The Social World of the New Testament. Insights and Models (Peabody, MA: Baker Academic 2008).

Neyrey, J.H., 2 Peter, Jude. A New Translation with Introduction and Commentary (The Anchor Bible 37C; New York: Doubleday 2004).

Neyrey, J.H., Render to God. New Testament Understandings of the Divine (Minneapolis, MN: Fortress 2004).

Nickelsburg, G.W.E., 1 Enoch 1. A Commentary on the Book of 1 Enoch, Chapters 1-36; 81-108 (Minneapolis, MN: Fortress Press 2001). 
Nickelsburg, G.W.E., Resurrection, Immortality, and Eternal Life in Intertestamental Judaism (Cambridge, MA: Harvard University Press 1972).

Petersen, D.L., Haggai and Zechariah 1-8. A Commentary (Philadelphia, PA: The Westminster Press 1984).

Pilch, J.J. - Malina, B.J., Biblical Social Values and Their Meaning. A Handbook (Peabody, MA: Hendrickson 1993).

Pitt-Rivers J.A., "The Place of Grace in Anthropology," HAU. Journal of Ethnographic Theory 1/1 (2011) 423-450. [Reprint from J.A. Pitt-Rivers, "Postscript: the place of grace in anthropology," Honor and Grace in Anthropology (eds. J.G. Peristiany - J.A. Pitt-Rivers) (Cambridge, UK: Cambridge University Press 1992) 215-246].

Reicke, B., The Epistles of James, Peter, and Jude. Introduction, Translation, and Notes (Garden City, NY: Doubleday 1964).

Robbins, V.K., Exploring the Texture of Texts. A Guide to Socio-Rhetorical Interpretation (Valley Forge, PA: Trinity Press International 1996).

Rohrbaugh, R.L. (ed.), The Social Science and New Testament Interpretation (Grand Rapids, MI: Baker Academic 1996).

Rowston, D.J., "The Most Neglected Book in the New Testament," New Testament Studies 21 (1975) 554-563.

Saller, R.P., Personal Patronage Under the Early Empire (Cambridge, UK: Cambridge University Press 1982).

Senior, D.P. - Harrington, D.J., 1 Peter, Jude and 2 Peter (Sacra Pagina 15; Collegeville, MN: Liturgical Press 2003).

Stewart, E.C., "Social Stratification and Patronage in Ancient Mediterranean Societies," Understanding the Social World of the New Testament (eds. D. Neufeld - R.E. DeMaris) (London New York: Routledge 2010) 156-166.

Stuhlmueller, C., Rebuilding with Hope. A Commentary on the Books of Haggai and Zechariah (Grand Rapids, MI: Eerdmans - Edinburgh: Handsel Press 1988).

Tromp, J., The Assumption of Moses. A Critical Edition with Commentary (Leiden: Brill 1993).

VanderKam, J., "Angel of Presence in the Book of Jubilees," Dead Sea Discoveries 7/3 (2000) 378-393.

Watson, D.F., Invention, Arrangement, and Style. Rhetorical Criticism of Jude and 2 Peter (Atlanta, GA: Scholars Press 1988).

Webb, R.L., "The Eschatology of the Epistle of Jude and Its Rhetorical and Social Functions," Bulletin for Biblical Research 6 (1996) 139-151.

Webb, R.L., "The Use of 'Story' in the Letter of Jude: Rhetorical Strategies of Jude's Narrative Episodes," Journal for the Study of the New Testament 31/1 (2008) 53-87.

Wolters, A., Zechariah (Historical commentary on the Old Testament; Leuven: Peeters 2014). 
